\title{
Rapid Toxicity Testing Based on Yeast Respiratory Activity
}

\author{
M. E. Haubenstricker, ${ }^{1}$ P. G. Meier, ${ }^{2}$ K. H. Mancy, ${ }^{2}$ and M. J. Brabec ${ }^{3}$ \\ 1 United States Environmental Protection Agency, Motor Vehicle Emissions \\ Laboratory, Ann Arbor, Michigan 48105; ' University of Michigan, School of \\ Public Health, Ann Arbor, Michigan 48109, and ${ }^{3}$ Eastern Michigan University, \\ Chemistry Department, Ypsilanti, Michigan 48197, USA
}

Rapid and economical techniques are needed to determine the effects of environmental contaminants. At present, the main methods to assess the impact of pollutants are based on chemical analysis of the samples. These procedures are time consuming and the reliability of a toxicity rating based upon their concentration is questionable, particularly in mixtures. The resultant toxic effect may be additive, synergistic, or antagonistic which at present can not be predicted from the toxicity data of individual chemicals.

Invertebrate and vertebrate exposures have been used over the last two decades in assessing acute and chronic toxicities. However, these tests are labor intensive and require several days to complete. Furthermore, results from whole organism toxicity tests are not easily interpretated in terms of mechanisms of toxicity.

An alternative to whole organism exposure is to determine toxic effects in monocellular systems, such as tissue cultures (Inmon et al. 1981), sperm cells (Dinnel et al. 1982), and bacteria (Curtis et al. 1982, Bulich et al. 1981). However, these tests also have disadvantages. Tissue and cell cultures require special facilities, and assessments may take from hours to days. While the bacterial assays are inexpensive and only take minutes to perform (Microtox bacterial assay system), they have not shown the same pattern of sensitivity to environmental samples as those elucidated in species such as fish (Qureshi 1982, Dutka and Kwan 1982).

Another approach for assessing toxicity is to monitor sensitive, nonspecific, subcellular target sites such as mitochondria (Ebina et al. 1980, Gopalaswamy and Aiyar 1984, Morita 1984, van Rossum et al. 1985, Wolf et al. 1982). This organelle is common to most eukaryotic cells of plants and animals, and is involved in a number of vital cellular processes. Changes in mitochondrial function (ie. state 3 and 4 respiration rates) which could indicate a toxic effect can be demonstrated readily after addition of a foreign substance (Figure 1).

In our initial assessments of various chemicals, rat liver mitochondria (RLM) were evaluated as a biological sensor of toxicity. However, the lability of mitochondria in vitro make them somewhat impractical for routine use as the sensor since they are very delicate and are easily damaged during isolation. Once extracted, RLM have a limited functional lifetime ( 24 to 48 hours) and are very sensitive to ions such as

Send reprint requests to M.E. Haubenstricker at the above address. 


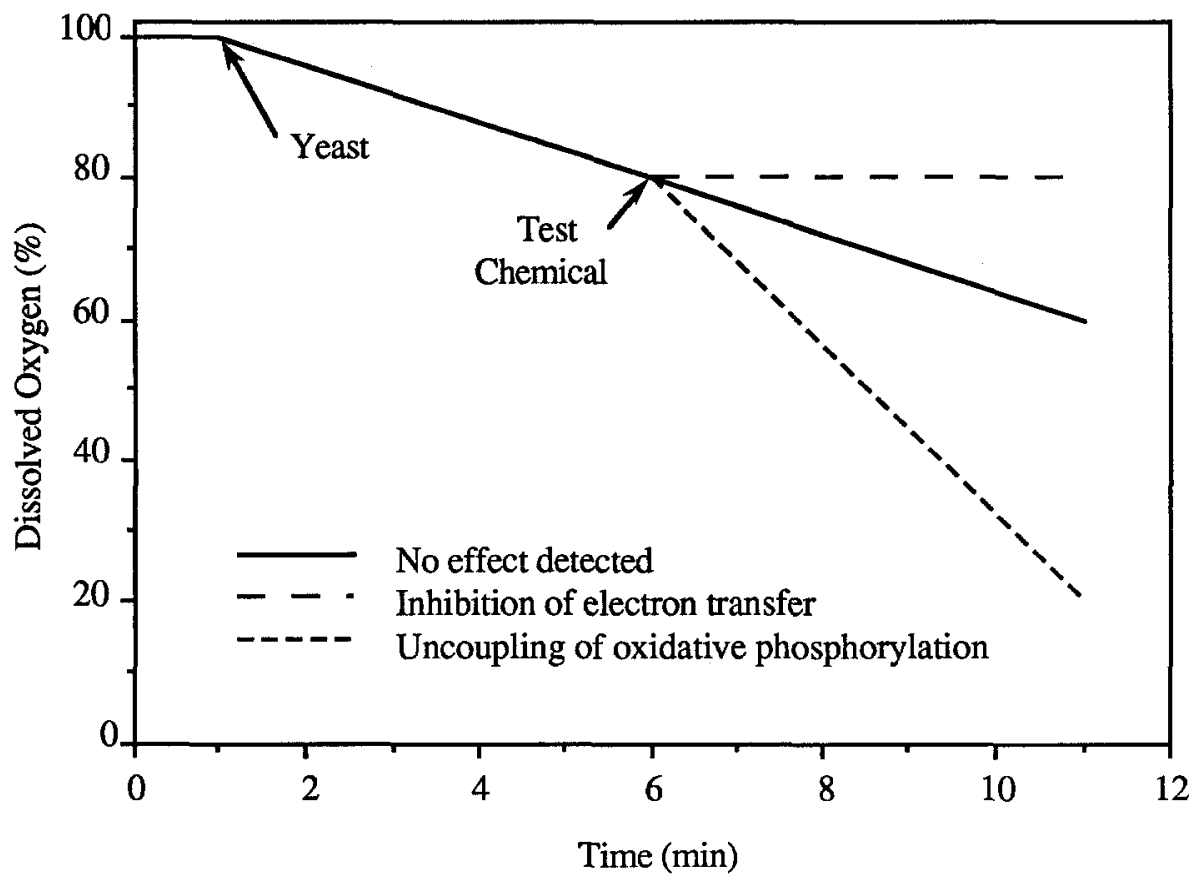

Figure 1. Ideal effects of chemical agents on yeast respiration.

calcium and iron. False toxicity assessments will result if these ions are present even though they are generally considered nontoxic. Because of these disadvantages, an alternative mitochondrial system, such as found in bakers yeast, was evaluated. Yeast are unicellular, more durable than isolated mitochondria, can be harvested without damage to the mitochondrial respiratory system, and are not affected when exposed to ions such as calcium and iron.

\section{MATERIALS AND METHODS}

The wild diploid strain of bakers yeast, Saccharomyces cerevisiae C 276 a/ $\alpha$ (Pringle, Department of Biological Sciences, The University of Michigan) was used as the biological sensor and was grown in YM-1 medium (Pringle et al. 1975). After the medium was autoclaved-sterilized, $50 \mathrm{~mL}$ of $20 \%$ ethanol was aseptically added to each $450 \mathrm{~mL}$ aliquot of the medium for a carbon supplement.

The yeast cells were grown at $37.5^{\circ} \mathrm{C}$ and aerated at $130 \mathrm{rpm}$ thoughout the incubation period. For assessment of respiration, cells were harvested by centrifugation at $1000 \mathrm{xg}$ for five minutes. The cells were then resuspended in 20 $\mathrm{mL}$ yeast respiration assay medium $(0.1 \mathrm{M}$ potassium phosphate in $2 \%$ ethanol, final $\mathrm{pH} 5.8$, and washed twice by centrifugation at $1000 \mathrm{x}$ g for five minutes. The final pellet was resuspended in $3-4 \mathrm{~mL}$ assay medium and chilled at $0-4^{\circ} \mathrm{C}$ until needed. Fractions of the final cell suspensions were sonicated for 20 seconds to disperse clumps (Branson S-75 ultrasonic sonifier) and counted with a model Zb electronic particle counter (Coulter Electronics) equipped with a $100 \mu \mathrm{m}$ diameter aperture tube (Pringle et al. 1975). 


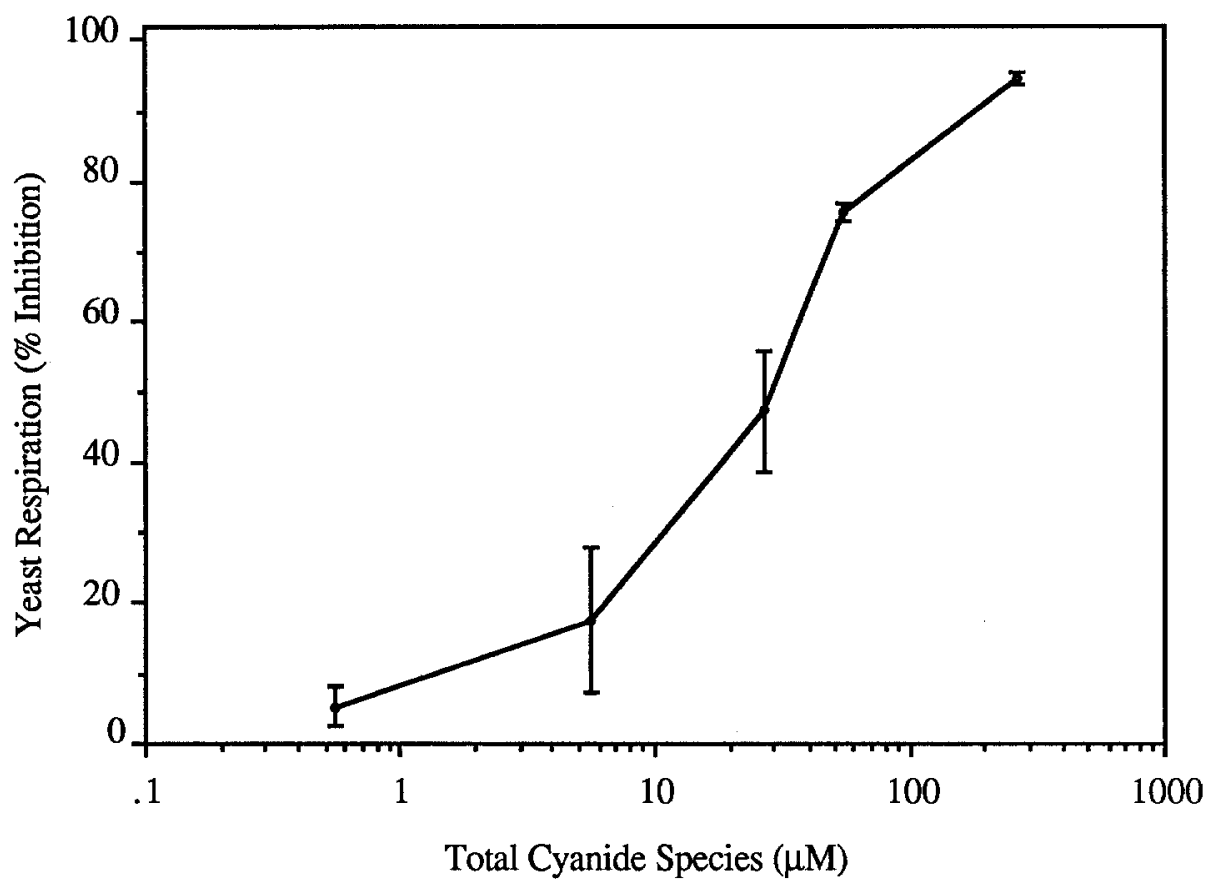

Figure 2. Effect of potassium cyanide on yeast respiration.

The oxygen electrode system (Yellow Springs Instruments, model \#53) was calibrated with deionized water which had dissolved oxygen (DO) concentrations ranging from $0-100 \%$ air saturation as determined by Winkler titrations (American Public Health Association 1975). Zero DO was obtained by the addition of sodium sulfite (Hitchman 1978).

For each toxicity test, $1 \times 10^{7}$ yeast cells were injected into the closed assay system containing $2.5 \mathrm{~mL}$ air saturated yeast assay buffer at $30.0^{\circ} \mathrm{C}$. After the initial respiration rate stablized, a volumetric quantity of a test sample was also injected. Since yeast cell membranes are impermeable to ADP, additions of ADP had no effect on the rate of respiration. Instead of determining state 3 and 4 rates and respiratory control ratios (RCR), percent change from control respiration rates were based on respiration before and after addition of the test solution.

Eleven of the test chemicals assessed in this study are listed in the United States Environmental Protection Agency (USEPA) list of water related priority pollutants (1979): isophorone, naphthalene, chlordane, n-nitrosodimethylamine, potassium cyanide, chloroform, diethyl phthalate, potassium dichromate, mercuric chloride, cupric chloride, and 2,4-dinitrophenol (2,4-DNP). Malathion was also included in this study as a representative of organophosphate pesticides. All solutions were prepared in deionized water, stored at $0-4^{\circ} \mathrm{C}$, and brought to room temperature before use. 
Table 1. $\mathrm{EC}_{50}$ values of yeast respiration for selected test chemicals.

$\begin{array}{lcr}\text { Chemical } & \text { Stimulation } & \text { Inhibition } \\ \begin{array}{l}\text { Potassium } \\ \text { cyanide }\end{array} & * & 30 \\ \begin{array}{l}\text { 2,4-Dinitro- } \\ \text { phenol }\end{array} & 200 & * \\ \begin{array}{l}\text { Mercuric } \\ \text { chloride }\end{array} & 100^{\mathrm{a}} & 185 \\ \begin{array}{l}\text { Cupric } \\ \text { chloride }\end{array} & 1470^{\mathrm{a}} & 8000\end{array}$

* No effective concentration determined.

aInitial stimulated response.

\section{RESULTS AND DISCUSSION}

The concentration of DO in air saturated yeast assay media was found to be 7.02 $\mathrm{mg} \mathrm{O}_{2} \cdot \mathrm{L}^{-1}$. The electrode response in deionized water was linear through the range of DO tested $\left(0-7.54 \mathrm{mg} \mathrm{O}_{2} \cdot \mathrm{L}^{-1}\right)$, with a sensitivity of $36.9 \mathrm{nAmpere} \cdot \mathrm{L} \cdot \mathrm{mg}^{-1}$. Forall assays: $\mathrm{T}=30.0 \pm 0.2^{\circ} \mathrm{C}, \mathrm{P}=750 \pm 5$ torr.

Malathion, isophorone, naphthalene, chlordane, diethyl phthalate, potassium dichromate, chloroform, and n-nitrosodimetnylamine (173 $\mathrm{nM}-72.2 \mu \mathrm{M}, 1.97$ $824 \mu \mathrm{M}, 99.2 \mathrm{nM}$ - $41.3 \mathrm{mM}, 55.2 \mathrm{pM}$ - 23.0 nM, 1.46 - $612 \mu \mathrm{M}, 11.3 \mu \mathrm{M}$ - 4.71 $\mathrm{mM}, 2.04-852 \mu \mathrm{M}$, and $3.94 \mu \mathrm{M}-1.64 \mathrm{mM}$, respectively) induced no detected effect on the rate of yeast respiration.

Cyanide ion (552 $\mathrm{nM}-271 \mathrm{mM})$ inhibited over-all respiration, which was characteristic of electron transfer inhibition (Figure 2), and 2,4-dinitrophenol (948 $\mathrm{nM}-396 \mathrm{mM}$ ) stimulated respiration, which was indicative of the uncoupling of oxidative phosphorylation from electron transfer.

Both mercuric and cupric ions (1.92-802 $\mu \mathrm{M}$ and $30.0 \mu \mathrm{M}-12.5 \mathrm{mM}$, respectively) caused an initial stimulation followed by an inhibition of respiration. This initial effect only persisted for a few minutes before the respiration rates decreased to values less than before addition of the test solutions. Similar effects of this type have been reported for $\mathrm{Ag}^{+}, \mathrm{Hg}^{2+}$, and $\mathrm{Cu}^{2+}$ on respiration in molds (Webb 1963), and for $\mathrm{Zn}^{2+}$ on respiration in isolated mitochondria (Kleiner 1974). These authors felt that an uncoupling of oxidative phosphorylation was followed by an inhibition of electron transfer. If this was the case, then this would help explain the variance that was generated in the initial stimulated respiration rates: inhibition of electron transfer caused a cessation of respiration which partially masked a stimulation produced by an uncoupling process. Concentrations of the test chemicals determined to produce a $50 \%$ effect $\left(\mathrm{EC}_{50}\right)$ on yeast respiration are presented in Table 1. Compounds tested that indicated no effect on yeast respiration are not included. 
A series of experiments were also carried out to evaluate the effect of "harvest" and "viability" of yeast on their respiration rate. Yeast cells sampled at different periods along the growth curve had very similar respiration rates for a set number of cells. Therefore, it was not necessary to harvest them at a specific point along the growth curve. Time-extended viability was also tested for up to 12 days after initially harvesting the yeast. No major change in respiration throughout this time was detected. The cells were stored at $0-4^{\circ} \mathrm{C}$ when not being assayed. On the twelfth day after harvest, the cells were evaluated with 2,4-DNP and with mercuric chloride. Similar results to those with freshly harvested yeast were observed, which indicated a rather long stability for the suspensions.

A dissolved oxygen electrode is used in this system to assess toxicity by monitoring changes in the respiratory rate of intact yeast cells. The described test is one of the most rapid and inexpensive methods ever suggested for screening contaminants in environmental samples. Although the yeast are generally not as sensitive as isolated RLM to indicate a toxic response, their prepartation, storage life, and physical durability make them more practical for a toxicity sensor of this type.

Acknowledgments. This work was supported by the United States Environmental Protection Agency.

\section{REFERENCES}

Bulich AA, Greene MW, Isenberg DL (1981) Reliability toxicity of pure compounds and complex effluents. In: Branson DR, Dickson KL (eds) Aquatic Toxicology and Hazard Assessment, ASTM STP 737. American Society for Testing and Materials, Philadelphia pp 338-347

Casarett LJ, Doull J (1980) Toxicology, the Basic Science of Poisons. 2nd ed Macmillan, New York pp 199-290

Curtis C, Lima A, Lozano SJ, Veith GD (1982) Evaluation of a bacterial bioluminescence bioassay as a method for predicting acute toxicity of organic chemicals to fish. In: Pearson JG, Foster RB, Bishop WE (eds) Aquatic Toxicology and Hazard Assessment, ASTM STP 766. American Society for Testing and Materials, Philadelphia pp 170-178

Dinnel PA, Stober QJ, Crumley SC, Nakatani RE (1982) Development of a sperm cell toxicity test for marine waters. In: Pearson JG, Foster RB, Bishop WE (eds) Aquatic Toxicology and Hazard Assessment, ASTM STP 766. American Society for Testing and Materials, Philadelphia pp 82-98

Dutka BJ, Kwan KK (1982) Application of four bacterial screening procedures to assess changes in the toxicity of chemicals in mixtures. Environ Pollut, ser A 29:125-134

Ebina S, Nakai S, Nagai Y (1980) Changes in mitochondria respiration and red blood cell morphology due to 2-haloethanols. Fukushima J Med Sci 27:11-24

Gopalaswamy UV, Aiyar AS (1984) Effects of lindane on liver mitochondrial function in the rat. Bull Environ Contam Toxicol 33:106-113

Hitchman ML (1978) Measurement of dissolved oxygen. In: Elving PJ, Winefordner JD, Kolthoff IM (eds) Chemical Analysis, vol 49. John Wiley and Sons, New York pp 88-90

Inmon J, Stead A, Waters MD, Lewtas J (1981) Development of a toxicity test system using primary rat liver cells. In Vitro 17:1004-1010

Kleiner D (1974) The effect of $\mathrm{Zn}^{2+}$ ions on mitochondrial electron transport. Arch Biochem Biophys 165:121-125 
Morita K (1984) Biochemical effects of manganese IV. Cooperative effects of manganese and vanadium on the energy transfer reaction of rat liver mitochondria. Okayama Igakkai Zasshi 96:353-358

Pringle JR, Mor JR (1975) Methods for montoring the growth of yeast cultures and for dealing with the clumping problem. Methods Cell Biol 11:131-168

Qureshi AA, Flood KW, Thompson SR, Janhurst SM, Inniss CS, Rokosh DA (1982) Comparison of a luminescent bacterial test with other bioassays for determining toxicity of pure compounds and complex effluents. In: Pearson JG, Foster RB, Bishop WE (eds) Aquatic Toxicology and Hazard Assessment, ASTM STP 766. American Society for Testing and Materials, Philadelphia pp $179-195$

Standard Methods for the Examination of Water and Wastewater (1975) 14th ed American Public Health Association, Washington pp 443-447

United States Environmental Protection Agency (1979) Water Related Environmental Fate of 129 Priority Pollutants. Vols A\&B, EPA-440.4-79-029, Washington

van Rossum GDV, Kapoor SC, Rabinowitz MS (1985) Effects of inorganic lead in vitro on ion exchanges and respiratory metabolism of rat kidney cortex. Arch Toxicol 56:175-181

Webb JL (1963) Enzyme and Metabolic Inhibitors, vol 1. Academic Press, New York pp 581-582

Wolf CR, Harmon H Schiller CM (1982) Interaction of aromatic aldehydes with isolated rat liver mitochondria. Biochem Pharmac 31:2025-2029

Received August 28, 1989; accepted November 20, 1989. 